*'59 '60

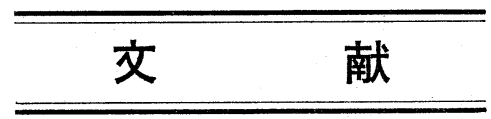

\section{1) 燃料一般}

カナダのエネルギー界の近況 C. L. O'Brian Can. Mining Met. Bull., 52, 569, 574.

1958年に乱ける西独のガス経済の発展 H. Lanrien他,

Gas u. Wasserfach, 100, 43, 1105.

北ドイッに打けるガス経済の諸問題 G. Düwel 同誌,

100,43, 1118. 「her, 同誌, 100,41/42, 1041. 欧州共同市場に竹けるェネルギー経済 F. Burgbacソーダ工業のエネルギー問題と将来 中沢治男, 化学

と工業，13,1,112.

ェネルギー長期計画の概要とエネルギー需給の現代に

ついて 成田寿治, 熱管理, 11, 9, $19 . \quad\lceil 9,25$. エネルギーをめぐる国際競争, 小暮光三, 同誌, 11, 輸入原油の現状，釜谷武，日石レビュー，2，1，7。

現在の化学工紫とエネルギー需給, 黒沢俊一, 化学と

工業, $13,1,5$.

$\Gamma 13,1,13$.

世界のエネルギー界の現状と将来, 安芸晈一, 同誌, 世界の石油資源とその生産需給, 平川芳彦, 同誌, 13 ,

$1,21$.

わが国石炭業界の現状，佐久洋，同誌， $13,1,34$.

日本の石炭企業のゆく光, 崎川範行, 同誌, $13,1,43$. 化学工業と電力, 佐川治男, 同誌, $13,1,48$.

鈌鋼工業とエネルギー，設楽正雄，同誌， $13,1,81$. カーバイド工業とェネルギー，青野武雄，同誌，13，

1, 86. 「同誌, 13, 1, 90 。 セメント製造に抢ける然料消費について, 内藤隆一, $13,1,95$.

ガラス工業とエネルギーの問題点, 宮崎雄一郎, 同誌, パルプ工業とェネルギー，井戸川春三，同誌， 13,1 , 102.

\section{2) 採炭, 採油, 選炭}

ブルドーザおよびドラグラインを使用しての有利な薄 層露天採炭、Coal Age, 64, 9, 106.

裮炭鉱山発展のための小規模な機械化 A. Hennecke, Bergbautech., 9, 8, 405.

「誌, 9, 8, 411 . 䄑炭釷山の排水坑道掘進機械化の可能性 P. Jolas, 同 蝎炭鉱山の補助作業, 雑作業の機械化 H. Ringling,

同誌, $9,8,420$.

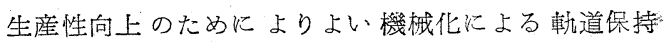

H. Meischner, 同誌, 9, 8, 423.

火攻法に対するいくつかの基準 P. Cooperman，J。 Appl. Phys., 30, 9, 1376. 「Eng., 11, 9, 904. パイプラインによる固体輸送 J. Nardi, Mining 連続採孷機のための切羽通気 J. D. Kalasky, 同誌,

11, 9, 928.

「Oil Gas J., 57, 41, 147.

頁岩を固化する新しいさく井用でい水W.J.Weiss他， 露天採炭に打いて $7,200 \mathrm{~V}$ に上る配電 R. V. Bovenizer, Mining Congr. J., 45, 10, 51.

天磐支保の進歩 J. T. Jones, 同誌, 45, 10, 85.

石岸採掘に工業技術の実際的適用 L. J. Prelaz, 同誌,

45, 10, 103.

坑内爆発ガス Coke \& Gas, 21, 243, 316.

坑内に打ける機械に上る運搬法, T. E. Green 他 Min-

ing, Elec., Mech. Mech. Engrs., 40, 467, 45.

ジグ洗炭機のエネルギーの簡易計算法 G. F. Eveson 他, J. Inst. Fuel, 32, 224, 398.

石炭工業比拈汁石研究課題 H. J. Rose, Can. Mining Met. Bull., 52, 569, 559.

1958年に括汀る Nova Scotia の铈産物工業 D. H。 Stonehouse, 同誌, 52, 569, 585.

Glyncorrwg 炭鉱再建 Colliery Eng., 36, 426, 334 . 坑内採掘機械展示会 同誌, $36,426,346$.

コンベヤ運搬のニュールック Mechanization, 23, 10, 重液選炭のために廃石利用 L. Walter, 同誌, 23, 10, 71.

選炭場で使用方る電気機械 W. H. Foster他, Mining, Elec., Mech. Engrs., 40, 468, 84.

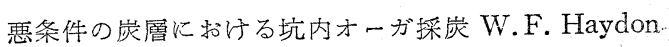
他, Mining Congr. J., 45, 11, 40.

企画された鉣業事業の経済的評価, 同誌, $45,11,43$ 。 各方向に延長できる新しいコンベヤ方式による薄層連

続採炭法, V. L. Hulery, 同誌, 45, 11, 67. 「72. 啥業界飞必要な研究, D. C. Minton, 同誌, 45, 11, 選炭場設計化打る電気的観点, D.E. Hamilton, 同 誌, $45,11,76$. 个学会誌, 28, 1, 23. 石炭の切削抵抗について (II) 江淵藤彦他, 九州鉣山, 海底油田の開発について, 山田秀夫, 石油学会誌, 3 , $1,3$. 
第 4 回国際石炭系会議記事, 藤本治義, 地質学雑誌,

$66,772,46$.

$\Gamma 13,1,117$.

採炭技術の最近に打ける進歩, 西島直己, 化学々工業, 採油技術の最近に拈ける進歩, 吉田半右衛門, 同誌,

13, 1, 127.

$\lceil 11,12,34$.

選炭法の現状とその傾向, 牛尾広惠, コールタール，

\section{3）石炭の性状と構造}

石炭の溶剤抽出物を電解して得られるフリーラジカル の研究, D. E. G. Austen他, Fuel, 38, 3, 309. 石炭の化学構造々性質, 第23報, ビトレインの電子自 転性共鳴，J. Smidt他，同誌，38，3，355.

石炭の紫外可視スペクトルと芳香族性 R. A. Friedel 他，同誌，38，3，369.

\section{4）乾留およびガス化}

ガス工業における難点, 開発拈よび発展の傾向 R. Schreiber, Energie, 11, 9, 439.

バイェルン地方のェネルギー経済におけるガス H. L.

Baath, 同誌，11，9，441.

ガスおよびュークス工業の副生硫酸アンモニウム Coke \& Gas, 21, 242, 261.

1959年度のガス工業, 同誌, 21, 242. 266；243, 331. BCURA（英国石炭利用研究協会）の仕事，同誌，21, $242,276$.

「択, 同誌, 21, 242,281.

コークス就よび工業に打汁る冷却系 III. 冷却方式の選 油から都市ガスの製造，同誌，21，242，291.

Murton コークス工場，同誌，21，243，306.

低温コークスの品質および収量に及ぼす無機添加物の

影響, R. G. Partington他, J. Inst. Fuel, 32, $224,417$.

都市ガスヘのブタン添加 Gas World, 150, 3919, 266. 混合ガス M. A. Hardie, Can. Mining Met. Bull., $52,569,582$.

石炭のガ ス液処理の軟鉄装置の応力窝食によるわれ

R.'N. Parkins他, J. Appl. Chem. (London), 9, 9, 445.

高分子石炭モデル物質によるコークス化機構の研究

V. 官能基団を有するモデル物質の熱分解 P. M. J.

Wolfs他, Brennstoff-Chem., 40, 10, 314. 「350.

Murton コークス工場 第 2 部 Coke \& Gas, 21, 244, 脱フェノールガス液の微生物酸化 E. H. M. Badger

他, 同誌，21, 244, 368 .

「244, 376.

ポーランドに打けるガス工業 A. Epsztein, 同誌, 21, 石炭乾留の科学 I, 同誌, $21,244,382$.
ガスの自動制御 Gas World, 150, 3920, 332.

イギリス乾留技術の展望 G. Cellan-Jones, 同誌, 150, 3920, Birth Suppl. 53.

家庭用コークスの粒度, 同誌,'150,3920, Coking 21, 無炭坑方式のガス化切羽の着火についてヴェー・ヴェ ー・グリゴーレフ他，ウーゴリ，18, 67.

縱型単筒連続式オイルガス発生炬について, 瀬戸口元

輔, 日本瓦斯協会誌, 12, 12, 11.

LPG の変成について, 前田康，同誌，12,12, 17 .

コークス炉の築炉から操業まで, 後藤弘, 同誌, 12,

$12,24$.

$\lceil 12,31$.

流動ガス 化炉の実繢について, 村田正二, 同誌, 12, 供給ガス中の有機硫黄について, 井筒和一郎, 同誌,

12, $12,35$.

「同誌，12, 12, 41. 都市ガスに対するLPG の混入限界について，浜田一，

5) タール

Houillères du Bassin de Lorraine (フランス) の Carling コークス工場でのベンゼンの水添精製, W. Fitz, Coke \& Gas, 21, 243, 321.

ピッチ生産に和ける鋼盘冷却用コンベヤの使用, 同誌, $21,243,336$.

南アフリカ産石炭加圧ガス化タールの新方法による研

究，I. 中性油研究の方法論 E. Terres 他, Erdäl u. Kohle, 12, 9, 734 .

石炭タール中の塩基性成分の研究, 近木尚他, 山口大 学理科報告, 10, 113.

$\lceil 11,12,4$.

鉄鋼と共に伸びる化学工業, 吉田尚, コールタール, ガスクロマトグラフィー拈よびその他の有機機器分析 のタール工業への応用, 武内次夫, コールタール, $11,12,25$.

\section{6) 石炭化学}

種々のピリジン誘導体による石炭の溶剤抽出実験 A. Halleux他, Fuel, 38, 3, 291.

アセチンンよりカーボンを形成する際のフェロセンの

影響，J. D. Frazee他，同誌，38，3，329.「333. 石炭から炭酸ガスの拡散 B. A. Bolt他, 同誌, 38, 3, 石炭業に打ける合理化と化学工業, 馬場有政, 化学経 済, 7, 2, 53 .

\section{7）石 油 精 製}

Nahorkatiya (Assam 地方) ガソリンの構造敊よび組 成, H.S. Rao他, J. Sci. Ind. Research (India), 18B, 9, 379 . 
協用作用 Refining Engr., 31, 12, C-15.

精油技術者のための工程ノートブック索引, 同誌, 31 , $12, \mathrm{C}-35$.

ドイッ原油からの重質ガソリンのプラットフォーミン グによる貴化結果 H. Pietsch他, Erdöl u. Kohle, $12,9,712$.

$\lceil 492,71$.

石油精製業について，宮城恭一，日本機栈学会誌，63， 石油精製技術の歴史々発展 VII. 異性化法, 山本雅一, 石油と石油化学, 4, 2, 64 . $\lceil 107$. 石油精製とエネルギー，林健樹，化学と工伹， 13，1，

\section{8)石油化学}

第 1 族から第 3 族むでの金属アルキル類によるエチレ ンの重合, K. Ziegler他, Angew. Chem., 71, 19, 625.

第 5 回世界石油会議 Brennstoff-Chem., 40, 10, 329 . ガルフコーストの石油化学工举 Refining Engr., 31,

$12, \mathrm{C}-6$.

$\mathrm{C}_{2}, \mathrm{C}_{3}$ 就よび $\mathrm{C}_{4}$ 族の石油化学の成長, 同誌, 31,12 , C-9.

合成ゴムの新しい発展，同誌，31，12，C-24. 「37. 無水マレイン酸括よびフマール酸, 同誌, $31,12, \mathrm{C}$ イソプレン, 同誌, $31,12, \mathrm{C}-41$.

鉱油の酸化機構の研究 II 化学的方法と分光的方法に より得た結果の比較 H. Luther他, Erdöl u. Kohle, 12, 9, 728.

過酸化水素によるガス状オンフィンのヒドロキシル化 堤繁他, 工業化学雑誌, $63,1,130$.

重合用触媒一オンフィン付加化合物の吸収スペクトル 飞よる研究，松本忠也他，同誌，63，1，165.

コバルト触媒によるプロピレンとアンモニアの反応， 山内健男他，石油学会誌，3，1，19.

合成ゴム工業について一特に世界に和ける合成ゴム事

情, 松田太郎, 洞誌, 3, 1, 30.

$\lceil 3,1,37$. わが国の石油化学製品生産の現状, 佐野英夫, 同誌, 石油留分の高真空蒸留々その応用, 河野信通, 化学工

業, 11，2，26.

ダウ触媒によるブタジェンの大量生産方式 R. J. Harbour, 同誌，11，2，31.

炭化水素からのアセチレン製造に扣ける最近の発達,

G.ファウザー, 石油と石油化学, $4,2,3$.

石油一化学一工学 藤田重文, 同誌, 4, 2, 28.

石油工業と工業用水, 豊田環吉, 同誌, $4,2,32$.

わが国石油系合成繊維の現況，長田弘，同誌，4，2，38.

パラフィン系炭化水素の気相酸化, 北原雅夫, 同誌,
$4,2,52$.

「谷治夫，同誌， $4,2,60$ 。 八ロ ゙ン化オレフィン系土壇燻蒸剤の最近の動向, 中 新しい化学工業の基礎原料, 堤繁, 化学経済, 7, 2, 41。 触媒の化学一酸化, 堤繁, 化学の領域, 14, 1, 27.

石油炭化水素のガスクロマトグラフィ一，木村元雄， 油化学, 9, 1, 8 .

「田稔, 同誌, 9, 1, 13. 石油重質留分のクロストグラフィーの最近の進歩, 藤 ペーパークロマトグラフィーの石油工業への応用, 野 瀬良治，同誌，9，1，19. 「孝他，同誌，9，1，25. 界面活性剤拈よび添加剤のクロマトグラフィー, 石渡 石油化学々石炭化学, 崎川範行, 日本瓦斯協会誌, 12 , $12,2$.

芳香族ジイソシアネートの合成とゴム製造への利用, 田中武英，コールタール，11, 12, 15.

\section{9）燃料油と潤滑油}

軸受潤滑に関する問題点の概観 A. Hundere, Lubri cation Eng., 15, 9, 358.

液体然料とガスタービン R. F. Darling, J. Inst。 Fuel, 32, 225. 475.

「報告，10，95。 境界潤滑の機構について, 德久正敏他, 山口大学理科

\section{0）燃焼と熱管理}

蒸気原動所のクリニック (診断) 第11部 I. J. Karassik, Combustion, 31, 3, 49.

単分子反応によつて生ずる炎の理論 I. 精密な数值解 J. O. Hirschfelder他, Phys. Fluid, 2, 5, 551 .

同上 II. 点火温度近似と他の型式の近似法, J.O. Hirschfelder他, 同誌, 2, 5, 565 .

$\lceil 1067$. 燃焼 R. Friedman他, Ind. Eng. Chem., 51, 9, ボイラ用加圧ジェッャオイルバーナ A. M. Brown, J. Inst. Fuel, 32, 224, 409.

$\lceil 421$. 清空法：必要性と適用 C. M. Opie，同誌，32，224， シェルボイラー：その歷史的展望 M. V. Murray， 同誌，32, 224, 425. 「Bull., 52, 569, 564 . 微粉宸の棟炭化 E. Swartzman, Can. Mining Met. 不完全燃焼に打ける空気数と然㜔效率 F. Schuster, Brennstoff-Chem., 40, 10, 326.

Murton ニークス工場の蒸気扣よび発電所 Coke \& Gas, 21, 244, 360. 「Fuel, 32, 225. 485. ドイツにおける大気活染の問題 $\mathrm{H}$. Lent, J. Inst. ガス暖房とそのガス経済に拈ける意義 $G$. Düxel,

Gas u. Wasserfach, 100, 41/42, 1049. 「1059. 最新式工業用ガス炉 Th. Schmidt, 同誌, 100, 41/42, 関西電力大阪発電所のボィラについて, 林田清, ボイ 
ラ技士，15, 1, 6 .

熱管理 1 年の回顧とこれからの諸問題, 春日進, 熱管

理, $11,9,7$.

「然燒，27, 1, 17 .

発電用ボイラの給水処理について, 鈴木寛一, 然料及

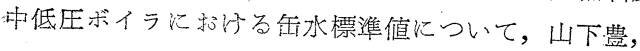

同誌, $27,1,37$.

鉄鋼一買工場飞招ける副生方ス配給の集中化方式，和 田光隆，同誌， 27, 1, 45.

脱酸銅熔解记括ける小型炬汇よる熱効率向上対策，影 山房太郎他，同誌，27, 1, 49.

精練染色工場の用水々排水処理について, 清水昭三,

同誌，27, 1, 53.

$\lceil 13,1,132$.

噴流推進燃料火現われた変化, 山崎毅六, 化学子工業, 強制貫流ボイラの過渡応答, 寺野寿郎, 日本機械学会 誌, $63,493,225$.

\section{1）分析・試験}

石炭灰中の燐の定量 R. J. Cosstick他, Fuel, 38, 3, 277.

「own他, 同誌, 38, 3, 295.

濠州炭の無機成分 I. 全鉱物分の直接定量 H. R. Brマンペクトルによる石炭の水添液体生成物の分析 $\mathrm{A}$.

G. Sharker 38, 3, 315.

過りえ酸塩中の硫酸塩の定量 A. G. C. Morris他,

Anal. Chim. Acta., 21, 3, $215 . \quad\lceil 1001,475$. 鉄治金工業见抢证る分析 B. Bagshawe, Analyst, 84, 大気中のトリクロルェチレンの定量用の Indicator tube の.夫 J. C. Gage, 同誌, 84, 1001, 509.

高周波加熱乾燥法に上るかつ炭拈よびかつ炭低温コー

クス中の水分の定量 J. Jandásek, Brennstoff-

Chem., 40, 10, 309.

20 点目盛接眼鏡の応用による石炭しま状成分の組織分

析法の単純化 K-Kötter, 同誌, 40, 10, 305.

抽出平衡汇ついての 2,3 の定量的考察 M. Oosting,

Anal. Chim. Acta, 21, 4, 301.

ガスクロマトグラフィーによる炭化水素含有ガスの分

析法 G. Scharfe, Erdöl u. Kohle, 12, 9, 723.

赤外線分光法の分析飞技汀る問題 R. Mecke, $Z$.

anal. Chem., 170, 1, 65.

赤外線分光学に和ける装置䄈よび技術の最近の進歩,

G. Bergmann，同誌，170, 1, 66 .

二置换ベンゼン誘導体の赤外線吸収強度測定法の比較

R. Mecke他，同誌，170, 1, 120.

ボンブカロリメータの研究 XI.種々のガスの発熱量測

定について R. A. Mott他, Fuel, 38, 3, 339.

X線の構造化学への応用, 富家勇次郎, 化学の領域,
$14,2,3$.

$\lceil 2,13$.

$\mathrm{X}$ 線回析法の工業化学的応用, 山口悟郎, 同誌, 14 , $\mathrm{X}$ 線透過法之透視法の工業的応用, 橋本宇一他, 同誌, $14,2,20$.

螢光 X線化学分析法, E. T. Hall他, 同誌, 14, 2, 25 . 光吸収分析法と爷の応用 (I) 武者宗一郎, 同誌, 14, 1,34 .

\section{2）化学工学むよび計測，制御}

空気拉よびアンモニアプラントの安全 Chem. Eng.

Progr. 55, 8, 69; 9, 49 .

$\lceil 9,86$.

コンピュータ・プログラムの抄録，同誌， $55,8,78$;

読みやすいフローダイセグラムの作り方 S. Fried-

man, Chem. Eng., 66, 17, 133.

有機化学比甜斿分子ぶるい P. Löwenberg， $J$. Appl. Chem. (U.S.S.R.), 9, 8, 417. 「55, 9. 35. プロセス評洒 R. F. West 他, Chem. Eng. Progr., 設計とスケールフップ一純理論的接近 D.Q. Kern,

同誌，55,9, 38 .

「同誌，55，9，44. ベンチスケールのパイロットプラント D.E. Garrett, 新しいぷラフィンワックス製造工場一その設誐飞装

置, 同誌, 55, 9, 92 .

壁面温度に階段状不連続のある乱流境界層内の温度拈

よび速度変動の測定 D. S. Johnson, J. Appl.

Mechanics, 26, 3, 325.

精留塔のガスクロマトグラフによる分析制御 R.C.

Halter他, Oil Gas J., 57, 41, 135.

多くのコントロールの問題を解決するアナログコンピ

ニータ, 同誌, $57,41,138$.

$\Gamma 57,41,140$.

デジタルコンピューター精油所自動化への鍵, 同誌,

コンピニータを用いてパイプラインを制御するための

手引き J. T. Manry, 同誌, 57, 41, 172.

交流ポーラログラフィー：データの正確度と計算過程

の検討 H. H. Bauer他, Australian J. Chem., 12, 3, 335.

同上：吸着過程のテンサィトリーによる研究，位相角

測定の有用性 H. H. Bauer 他, 同誌，12，3，343.

ベンゼン扰よびへキサィチルベンゼンのエネルギー準

位の改良した逆対称分子軌道関係による計算 F.A.

Gray他，同誌，12，3，347.

単分子膜の貯蔵水の蒸発に与兄る影響 $\mathbb{V}$. 固体からの

単分子膜の拡がり W.W. Mansfield, 同誌, 12, $3,382$.

気一液平衡 $\mathbb{X} .45^{\circ} \mathrm{C}$ に拈けるnープロパノール十ベン ゼン拉よびnーブタノール十ベンゼン系 I. Brown他， 
同誌，12,3，407.

配管系の升の人力遠隔制御 A. L. Forrester, Coke \& Gas, 21, 242, 292.

制御用測定，同誌，21，243，338. 「51，9，1056. アルキル化 L. F. Albright et al., Ind. Eng. Chem., 還元によるアミノ化 J. Werner, 同誌, $151,9,1065$. 宸化水素の熱扣よび接触分解 A. J. deRosset 他, 同 誌, 51, 9, 1075.

エステル化 M. L. Peterson 他, 同誌, 51, 9, 1081. Friedel-Crafts アシル化法 K. LeR. Nelson, 同誌,

51, 9, 1099.

八ロ ケン化 L. R. Belohlav 他, 同誌, 51, 9, 1102. 水素化と脱水素 J.T. Bradbury他, 同誌, 51，9, 1111 . 異性化 S. F. Perry, 同誌, 51, 9, 1121.

二卜ロ化 W. R. Tomlinson, 同誌, 51, 9, 1123.

液相酸化 W. G. Toland, 同誌, 51, 9, 1130.

重合 F. H. Bolston, 同誌, 51, 9, 1135.

石炭とシシェールの熱分解 C. H. Prien 他, 同誌,

$$
\text { 51, 9, } 1142 .
$$

スルフォン化と硫酸化 E. E. Gilbert 他, 同誌, 51, 回転軸用パッキン箱のシーリング特性 D. F. Denny

他, Chartered Mech. Engr., 6, 8, 373.

化学工場に怙ける工程操作からのデータ処理 F. G.

Webster, Trans. Soc. Instruments Tech., 11, 3, 190.

回転半径の大きい遠心分離機を使用した沈降法による

粒子径の測定 A. K. Gupta, J. Appl. Chem. (London), 9, 9, 487.

強塩基性陰イオン交換樹脂の交换容量の測定 A. L.

Wilson, 同誌, 9, 9, 466.

有機窝食抑制剂一その作用之使用 G. E. Purdy， Erdöl u. Kohle, 12, 9, $743 . \quad$ 「244, 372. ガス拉よ゙コークスによる乾燥 Coke \& Gas, 21， 充填塔の液側有効接触面積, 疋田晴夫他, 化学工学,

24, 1, 2. 「の影響, 㱜田晴夫，同誌，24，1，9. 充填塔の液側物質移動速度に打よ添す表面活性剤添加 充埧層の有效熱伝導度, 杉山幸男他, 同誌, $24,1,12$. ヘンンチュリー管に扣ける空気流による圧打損失, 吉田 哲夫他, 同誌, 24, 1, 20.

「誌, 24, 1, 28. 水ジェットスクラッバーの基礎実験, 木村典夫他, 同 湿式粉砕トリコンミル, 小山田貞幹, 同誌, $24,1,45$. 自動制御発達の新段階, 高橋安人, 日本機械学会誌,

63, 492, 187.

$\lceil 2,2,7$. パッキンの使い方とその材料, 松下一男, 化学装置, 水処理について, 阿部精爾, 同誌, $2,2,18$.
日本に打ける大気洉染の現状，鉿木武夫，科学，30， 2, 84. 「て，ボイラ技士， 15，1，33. 水の気曝, 脱炭酸ガス, 脱気ならびに薬品注大につい 攪拌と攪拌装置, 薏藤一夫他, ケミカル・エンジニヤ リング， $5,2,1$.

福拌装置のスケールアップ, 中島敏, 同誌, 5, 2, 11. サイドェンタリングミキサとトップエンタリングミキ サ, 高坂潔他, 同誌, 5, 2, 19 .

$\Gamma 2,40$.

高温高圧手の問題点について, 和田伝之助, 同誌, 5 , 化学工学よりみた石油工業, 矮木栄, 石油学会誌, 3 , $1,7$.

二成分系共沸物の共沸圧力, 共沸温度, 共沸組成につ

いて，山田幾穂他，同誌，3，1，25.

管理について，朝香鉄一，蓺管理，11,9，11.

プロセス目動制御の動向, 寺尾満, 同誌, 11, 9, 14 .

水淨用金属触媒について（2）山中竜雄, 石油と石油 化学, 4, 2, 22 .

流量制御法 (1) 計測， 10，1，31。 「誌，10，1，39。 プロセス計装に扮ける諸問題について, 藤田威雄, 同 蒸留塔還流の計算機制御, 遠山武(訳), 同誌, $10,1,48$. ガスエンジンコンプレッサーについて, 斎藤芳男, 高

圧ガス協会誌，24，1，2.

「究報告, 8, 2, 1 .

管内層流熱伝達の固有值について, 広島大学工学部开 界面活性剤の親水・親油性バランス，岡由正香；化学 の領域, 14, 1, 39.

$\lceil 27,1,1$. ガ ス赤外線乾燥について, 塙阪淳次, 燃料及然㜔, 工䍴用水処理にイオン交换装置を利用する場合の諸条 件，池田泰三，同誌，27，1，12.

新しい流量計招よび圧力計，川崎壉，同誌，27，1，25. 生藏の乾燥について, 高田耕一, 同誌, $27,1,59$.

特殊ガスクロマトグシフィー, 功刀泰碩他, 油化学,

$9,1,2$.

アメリカの用水問题, 安芸瞈一, 用水々廃水, $2,1,2$. 人工地下水に上る工業用水の循環使用について広瀬孝 六郎, 同誌, 2, 1, 25.

$\lceil 2,1,45$.

河川水中の溶存酸素の平衡について, 岩井重久, 同誌, 水質基準と工場廃水の放流, 清浦雷作, 同誌, 2, 1, 53 . 海田工場に打ける活性污泥法による排水処理, 滰村延

雄, コールタール, 11, 12, 9

13）雑

超音速噴流中に括けるガス混合物の分離 P. C. Waterman代, J. Chem. Phys., 31, 2, 405.

火力発電所建設にあたつての眫音防止対策。L. Cremer 他, Energie, 11, 7, 311. 
水ーエタノール系に括忷る $\mathrm{U}(\mathrm{IV})-\mathrm{U}(\mathrm{V})$ 電子交換反 応の活性化ェネルギー, A. Indelli 他, J.Am. Chem. Soc., 81, 16, 4180.

触媒液相水素化の速度論 I. コロイド状ロジゥムおよ びパラジゥム上での芳香族ニトロ化合物の水素添加 H.-C. Yao 他, 同誌, 81, 16, 4125.

炭化水素の酸化, 第 2 部, 無水醋酸溶液中に捣けるシ クロペンテン，3ーメチルシクローキセン扰よ゙テト ラリンの酸化 R. H. Snyder他, 同誌,81，16, 4299. 製鋼法の展望 T. P. Colclough, J. Iron "\& Steel Inst. (London), 192, 3, 201.

ラビリンスパッキンの漏れの解析 W. Zabriskie他, J. Basic. Ind., 81, 3, 332.

軸流圧縮機翼列の空気力学的解析, 第 1,2 部, G. L. Mellor, 同誌, 81, 3, 362, 379. 「誌, 81, 3, 401. ガスターゼン機関の失速の予知 R. J. Rubick 他, 同 実験と理論からみた失速の成長の調查, H. W. Emmons他, 同誌, 81, 3, 409. $\lceil 3,417$. 失速成長に括斿る変調現象 J.A. Rockett, 同誌, 81,

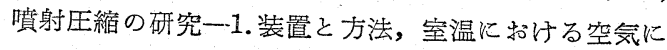
よる結果について H. J. Hoge 他, 同誌, 81, 3, 426. 「Anstratian J. Chem., 12, 3, 309. 脂環族炭化水素第 2 ビリアル係数 H. G. David 他, カーボンゾラック中の過酸化物 V. A. Garten他, 同 誌, 12, 3, 394.

危険な山るいは窗食性のある場所に扢ける照明器具の 適切なる使用法 Coke \& Gas, 21, 242, 286. ラネーニッケル触媒中の水素の役割 R. J. Kokes 他, J. Am. Chem. Soc., 81, 19, 5032. 「9, 1161. 岸素と黒鉛 W. M. Gaylord, Ind. Eng. Chem., 51, 鉄，岸素鋼扰上び合金鋼 R. W. Vandesbeck他，同

誌, 51, 9, 1178.

保護被濖 F. Scofield，同誌，51，9，1213. チーグラ型ポリェチレン M.N. Berger他. J.Appl-
Chem. (London), 9, 9, 490.

Koppers 法に上る炭化水素の熱分解 P. Schnek, Erdöl u. Kohle, 12, 9, 717.

宸化水素と炭化弗素混合物の第 2 ビリアル係数 M. D.

G. Garner他, Trans. Faraday Soc., 55, 9, 1524. 接触角怙よび毛細管王力に対する古典的方程式の基本

R. E. Collins他，同誌，55，9，1602.

液一一液界面の熟成, 第 1 部, 收縮射出法の補正 F. H.

Garner 他，同誌，55，9，1607.

同上，第 2 部，水中の有機化合物の鎖の長さや構造の 影響 F. H. Garner他, 同誌, 55, 9, 1616.

酸化エチンンおよびその類似化合物とスチレンとのプ ロック重合物 D. H. Richards他, 同誌,55, 9, 1644 。 不均一一応関する新しい根本的意見 $\mathbb{I}$. 䀦相一液相

界面に抢ける遷移層の熱力学 L. Imre, Kolloid-z., $166,2,122$.

高分子拉よびコロイド溶液の粘度の濃度沶よび温度低 存性の実測值と球状模型を基本として流体力学的に 求めた理論式との比較 L. Andrussow, 同誌, 166, $2,135$.

$\Gamma 63,492,3$. わが国鉄鍋生産技術の展望, 山岡武, 日本機械学会誌, 最近の耐熱材料の進歩, 中村素, 同誌, 63, 492, 12 . 航空エンジンの現状, 永野治, 同誌, $63,492.166$. ガスタービンの現状，須之部量寬他，同誌，63，492， 178. $\lceil 14,2,3$.

$\mathrm{X}$ 線の構造化学への応用, 富家勇次郎, 化学の領域, 反応性ガスカ学に批ける境界層問題, 过広, 東京大学 航空研究所集報, 1, 6, 384.

理想液体の㠜集力について（第 4 報）パラフィン系炭 化水素敄よびその誘導体分子のらせん鎖構造々物質 の交互性ならびにそれらの液体の㠜集力と沸点との 関係について, 小塚多吉, 日本化学雑誌, 81, 1, 26.

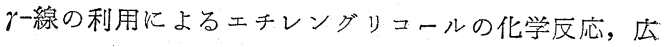
田鋼藏他，同誌，81, 1, 29.

\begin{tabular}{ll}
\hline 会 & 報 \\
\hline
\end{tabular}

\section{第 106 回常議員会並びに第29回評議員会報告}

1. 日 時 昭和35年 1 月 14 日（木）午前11時半

1. 場 所 東京都港区赤坂葵町共済会館会議室

1. 出席者 黒川会長, 海内, 馬場両副会長, 黒田, 新村, 古市, 水谷各参与員, 雨宮, 岩崎, 下村, 西島(代), 二宮, 藤江, 矢毛石,
山口, 山㱦, 山本, 各常議員, 安藤(代), 内山(代), 大坪(代), 久保(代), 武谷, 堤, 百武, 山田各評議員, 宮崎, 村山両: 監事

1. 議題

（1）通常会員総会提出議案承認の件

（1）昭和 34 年度会務報告の件 